\title{
Studies on the Synthesis and Reactivity of Novel Benzofuran- 2-yl-[3-Methyl-3-Phenylcyclobutyl] Methanones and their Antimicrobial Activity
}

\author{
Murat Koca ${ }^{1}$, Misir Ahmedzade ${ }^{1}$, Alaaddin Çukurovali ${ }^{1, *}$ and Cavit Kazaz ${ }^{2}$ \\ ${ }^{1}$ Firat University, Faculty of Arts and Sciences, Chemistry Department, 23119 Elazig, Turkey \\ ${ }^{2}$ Ataturk University, Faculty of Arts and Sciences, Chemistry Department, Erzurum, Turkey \\ *Author to whom the correspondence should be addressed; e-mail: acukurovali@firat.edu.tr
}

Received: 7 January 2004; in revised form: 10 February 2005 / Accepted: 15 February 2005 /

Published: 31 August 2005

\begin{abstract}
Preparation in excellent yields of cyclobutyl benzofuran-2-yl- and naphthofuran2-yl-ketones, the corresponding ketoximes and thiosemicarbazones, ether derivatives of the ketoximes and thiazoles derived from the thiosemicarbazones are described. Two of the synthesized compounds have been tested against eight different microorganisms and found to be active against some of the species studied.
\end{abstract}

Keywords: Furans, cyclobutane, oxime, thiazole, thiosemicarbazone.

\section{Introduction}

Synthetic benzofuran derivatives have received considerable attention owing to their antifungal $\mathrm{N}$-myristoyl transferase inhibitor activity [1] and their activity as potent non-steroidal reversible inhibitors of $\mathrm{P} 450$ aromatase [2]. On the other hand, the electron-transfer-catalyzed [2+2] cycloreversion of cyclobutanes has important biological implications in splitting the cyclobutane-type pyrimidine dimers in UV damaged DNA [3, 4], and may have potential applications for photochemical energy storage [5]. The benzofuran ring system itself is a common structural element that appears in a large number of medicinally important compounds [6]. Benzofuran neolignans and nor-neolignans, which are contained in most plants, have attracted much attention in medicinal chemistry for their wide range of various biological activities, including insecticidal, fungicidal, antimicrobial and antioxidant properties [7]. 
The present investigation was performed for the purpose of synthesizing derivatives of benzo- and napthofuran-2-yl-[3-methyl-3-phenylcyclobutyl]-methanones. These derivatives are oximes, epoxy ether derivatives of the oximes, thiosemicarbazones and thiazoles. This approach seems to be useful in view of the fact that it may combine the physiological action of the two groups with the well-known biological activity of the compounds containing cyclobutane, thiazole and benzofuran groups. As far as we know this is the first report on these substances.

\section{Results and Discussion}

The synthetic route followed is shown in Scheme 1. One of the starting compounds, 3-phenyl-3methyl-1-(2-chloro-1-oxoethyl)cyclobutane, was synthesized according to the general procedure described in [8], starting from acrolein and dry chlorine, and subsequently isobutylene. Benzofuran derivatives were prepared from 2-hydroxy-5-bromobenzaldehyde or 2-hydroxy naphthalaldehyde and 3-phenyl-3-methyl-1-(2-chloro-1-oxoethyl) cyclobutane in different solvents.

\section{Scheme 1}<smiles>O=Cc1cc(Br)ccc1O</smiles><smiles>CC1(c2ccccc2)CC(C(=O)CCl)C1</smiles><smiles>[R][R]C(=O)C1CC(C)(c2ccccc2)C1</smiles><smiles>CC1(c2ccccc2)CC(C([R10]#CCON)=NO)C1</smiles>

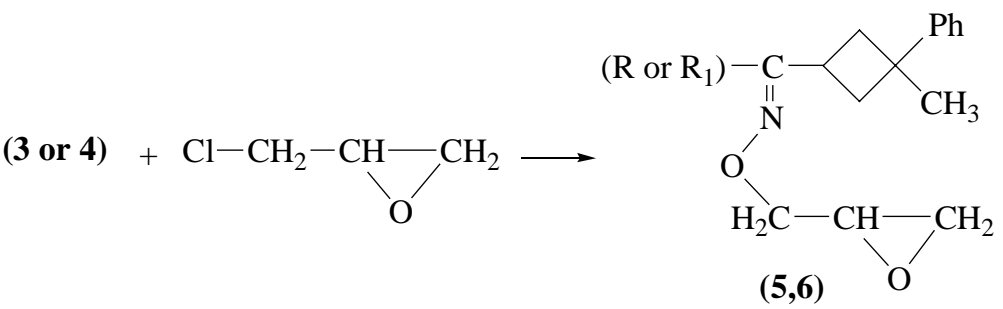<smiles>[R]OC(=O)C(=NNC(N)=S)NNc1nc(CCl)cs1</smiles> 
The first reaction involves a nucleophilic substitution reaction in acetone between 3-phenyl-3methyl-1-(2-chloro-1-oxoethyl) cyclobutane and the potassium salts of 2-hydroxy-5-bromo benzaldehyde or 2-hydroxynaphthalaldehyde. As a result of: (i) the strong nucleophilicity of the potassium salts of aldehydes, (ii) the absence of steric hindrance by 3-phenyl-3-methyl-1-(2-chloro-1oxoethyl) cyclobutane and (iii) the increased positive charge of the positive center of the carbocation formed by the elimination of chloride from the latter, due to the inductive effect of chlorine atom, the acetone solvent provides a relatively mild temperature conditions for the formation of the expected substances with excellent yields. In Scheme 1, the compounds 1, 3, 5, 7, and 9 have the R substituent, while $2,4,6,8$, and 10 include the $\mathrm{R}_{1}$ one.

The first compound, benzofuran-2-yl-(3-methyl-3-phenylcyclobutyl) methanone (1), is prepared in the presence of potassium carbonate in excellent yield (94\%). It was expected that this compound should have two different isomers in the cis and trans configurations, due to the methyl and phenyl groups on the cyclobutane ring may. In fact, the starting material, 3-phenyl-3-methyl-1-(2-chloro-1oxoethyl) cyclobutane itself is an 85:15 mixture of cis and trans isomeric structures [8]. Unfortunately, only one isomer was separated, possible a result of the crystallization technique. In the second step, this compound was converted into its corresponding oxime 3 in 4:1 alcohol-water in the presence of pyridine by a well known method. The yield of the reaction was good (74\%). As is known, oximes can be found in two different isomeric structures namely, the syn and anti configurations [10,11]. As expected, compound 3 (and similarly compound $\mathbf{4}$ ) shows two different isomeric structures. As can be seen from its ${ }^{1} \mathrm{H}-\mathrm{NMR}$ spectra, both $-\mathrm{CH}_{3}$ and oxime $(\mathrm{N}-\mathrm{OH})$ groups have double peaks. The oxime group has a descreening effect [9], and thus the low-field signals are assigned to the $E$-isomer, while the signals at the high-field are assigned to the $Z$-isomer. Since the ratios of the $E$ - and $Z$ - isomers in the initial ketoximes and in the alkylation and acylation reaction products does not coincide in most cases, a partial E/Z-isomerization probably takes place.

Reactions of $\mathbf{3}$ and $\mathbf{4}$ with epichlorohydrin, in the presence of $\mathrm{KOH}$, gave oxime ethers $\mathbf{5}$ and $\mathbf{6}$. It is expected that these compounds must also be in different isomeric structures and it has been seen from the ${ }^{1} \mathrm{H}$-NMR spectra, that indeed these compounds are isomeric mixtures. Some functional groups of these compounds showed double peaks in the ${ }^{1} \mathrm{H}$-NMR spectra. Especially, substance 5 has two singlets at 1.57 and $1.62 \mathrm{ppm}$ for $-\mathrm{CH}_{3}$ and four doublets at 4.12-4.50 ppm range for $\mathrm{N}-\mathrm{O}-\mathrm{CH}_{2}$ protons. When doublets are expanded, some additional doublets are shown. These results mean that these compounds have different isomeric structures resulting from cis and trans isomers on cyclobutane ring and syn and anti isomers on the oxime or the mixtures of these isomeric structures. Each one of the remaining four compounds 7, 8, 9 and 10 has only one isomeric structure.

The ${ }^{13} \mathrm{C}$-NMR resonances and IR data which are given in the Experimental section and the elemental analysis results confirm the identity of the compounds. All the compounds synthesized here are solid substances, stable at room temperature and not affected by atmospheric conditions over at least in two weeks. On the other hand, as these compounds contain cyclobutane, benzofuran, Schiff base, carbazone and thiazole functions in their molecules, they seem to be suitable candidates for further chemical modifications and may be pharmacologically active and useful as ligands in coordination chemistry.

For the biological evaluation of the compounds prepared some representative examples were screened against eight different microorganisms (six bacteria and two yeasts). The test results obtained are listed in Table 1. Antifungal and antibacterial data for ampicillin and nystatin are also included in 
this Table for the purpose of comparison. The data show that these compounds generally exhibited moderate toxicity in the high concentrations towards many of the bacterias tested. Unexpectedly both of the substances tested showed no toxicity against all the yeasts. Biological activity studies of the substances on some other different bacterias and yeasts are in progress.

Table 1 Antimicrobial effect of the compounds*

\begin{tabular}{|c|c|c|c|c|c|c|c|c|}
\hline Compound & $\begin{array}{c}\text { B. s. } \\
\text { LM622 }\end{array}$ & $\begin{array}{c}\text { E. a. } \\
\text { CCM } \\
2531\end{array}$ & $\begin{array}{c}\text { E. c. } \\
\text { ATCC } \\
25922 \\
\end{array}$ & $\begin{array}{c}\text { L. m. } \\
\text { SCOTTA }\end{array}$ & $\begin{array}{c}\text { P. a. } \\
\text { DSM 5007 }\end{array}$ & $\begin{array}{c}\text { S. a. } \\
\text { COWAN I }\end{array}$ & $\begin{array}{c}\text { C. a. } \\
\text { FMC } 17\end{array}$ & $\begin{array}{c}\text { S. c. } \\
\text { FMC } 16\end{array}$ \\
\hline 7 & 9 & 6 & 9 & 9 & - & 9 & - & - \\
\hline 8 & 8 & 10 & 8 & 10 & 8 & - & - & - \\
\hline A.50 & 34 & - & 33 & 46 & - & 43 & - & - \\
\hline B.50 & - & - & - & - & - & - & 18 & 22 \\
\hline
\end{tabular}

* For microbe species see Experimental. Compound concentrations $=500 \mu \mathrm{g} / \mathrm{disc}$. Including disc diameter (6 mm), A.50: Ampicillin $50 \mu \mathrm{g} /$ disc, B.50: Nystatin $50 \mu \mathrm{g} /$ disc. The symbol (-) means that the compounds have no activity against the micro organisms.

\section{Experimental}

\section{General}

Benzene, acrolein, benzaldehyde and amines were purchased from Merck and used as received. Melting points were determined on a Thomas Hoover melting point apparatus and are uncorrected. The IR spectra were measured with Mattson 1000 FT-IR spectrophotometer. The ${ }^{1} \mathrm{H}$-NMR spectra were recorded on a Varian-Gemini $200 \mathrm{MHz}$ spectrometer and are reported in ppm ( $\delta$ ) relative to tetramethylsilane (TMS) as the internal standard and ${ }^{13} \mathrm{C}-\mathrm{NMR}(50.34 \mathrm{MHz})$ is referenced to deuterochloroform $\left(\mathrm{CDCl}_{3}\right)$. Elemental analyses were determined on a LECO CHNSO-932 auto elemental analysis apparatus. Analyses (TLC) were performed on precoated $0.2 \mathrm{~mm}$ Merck kieselgel $60 \mathrm{~F}_{254}$ plates, visualizing with $254 \mathrm{~nm}$ UV lamp. Column chromatography was performed using Merck silica gel, 70-230 mesh. Solvents were dried and purified by known conventional methods prior to use. As the preparation for the ten compounds are identical in pairs, we describe below the synthesis of $\mathbf{1}, \mathbf{3}, \mathbf{5}, \mathbf{7}$ and $\mathbf{9}$ as representative examples for all the compounds.

General procedure for the synthesis of ketones 1 and $\mathbf{2 .}$

In a two necked $250 \mathrm{~mL}$ flask equipped with a reflux condenser, a mixture of 5-bromosalicylaldehyde (4.02 g, $20 \mathrm{mmol}$ ), potassium carbonate (2.76 g, $20 \mathrm{mmol}$ ) and 3-phenyl-3-methyl-1(2-chloro-1-oxoethyl) cyclobutane $(4.45 \mathrm{~g}, 20 \mathrm{mmol})$ in acetone $(100 \mathrm{~mL})$ was refluxed for $8 \mathrm{~h}$. The solvent was removed under reduced pressure and the residue was extracted with diethyl ether, the etheral phase dried over anhydrous $\mathrm{MgSO}_{4}$, filtered and the solvent removed under reduced pressure. Solid substance 1 thus obtained was crystallized from acetone. 
(5-Bromo-1-benzofuran-2-yl)(3-methyl-3-phenylcyclobutyl)methanone (1). Yield: 6.93 g (94\%); m.p.: 134-135 ${ }^{\circ} \mathrm{C}$ (from acetone); IR (KBr): $1674(\mathrm{C}=\mathrm{O}), 1255$ (C-O, on furan ring), 542 (C-Br) cm ${ }^{-1}$; ${ }^{1} \mathrm{H}-\mathrm{NMR}\left(200 \mathrm{MHz} ; \mathrm{CDCl}_{3}\right) \delta: 1.64$ (s, 3H, $\left.\mathrm{CH}_{3}\right), 2.49$ (m, 2H, $\left.\mathrm{CH}_{2}\right), 2.81\left(\mathrm{~m}, 2 \mathrm{H}, \mathrm{CH}_{2}\right), 4.08(\mathrm{q}, 1 \mathrm{H}$, >CH-), 7.15-7.83 (m, 9H, aromatics); ${ }^{13} \mathrm{C}-\mathrm{NMR}$ (50.34 MHz; $\mathrm{CDCl}_{3}$ ) $\delta: 193.74(\mathrm{C}=\mathrm{O}), 156.19,154.90$, 152.99, 133.04, 130.97, 130.34, 127.68, 126.64, 126.11, 118.93, 115.98, 113.77, 40.88, 38.97, 38.84, 32.54. Anal. Calcd. For $\mathrm{C}_{20} \mathrm{H}_{17} \mathrm{BrO}_{2}$ : C 65.05, H 4.64. Found: C 65.04, H 4.60.

(3-Methyl-3-phenylcyclobutyl)(naphtho[2,1-b]furan-2-yl)methanone (2). Yield: 1.18 g (74\%); m.p.: $148{ }^{\circ} \mathrm{C}$ (from ethanol); IR (KBr): 1674 (C=O), 1255 (C-O, on furan ring) $\mathrm{cm}^{-1}$; ${ }^{1} \mathrm{H}-\mathrm{NMR}$ (200 MHz; $\left.\mathrm{CDCl}_{3}\right) \delta: 1.69$ (s, 3H, $\left.\mathrm{CH}_{3}\right), 2.53\left(\mathrm{~m}, 2 \mathrm{H}, \mathrm{CH}_{2}\right), 2.88\left(\mathrm{~m}, 2 \mathrm{H}, \mathrm{CH}_{2}\right), 4.17$ (q, 1H, >CH-), 7.17-8.18 (m, $12 \mathrm{H}$, aromatics); ${ }^{13} \mathrm{C}-\mathrm{NMR}\left(50.34 \mathrm{MHz} ; \mathrm{CDCl}_{3}\right) \delta: 193.36(\mathrm{C}=\mathrm{O}), 155.97,153.75,153.17,132.53$, 131.72, 131.08, 130.32, 130.21, 129.38, 127.62, 127.51, 126.69, 125.37, 124.95, 114.78, 113.73, 40.91, 39.13, 38.66, 32.54. Anal. Calcd. For $\mathrm{C}_{20} \mathrm{H}_{17} \mathrm{BrO}_{2}$ : C 84.68, H 5.92. Found: C 84.57, H 5.61.

\section{General procedure for the synthesis of ketoximes $\mathbf{3}$ and $\mathbf{4}$.}

Compound 1 (3.689 g, $10 \mathrm{mmol}$ ), hydroxylamine hydrochloride (0.781 g, $12 \mathrm{mmol}$ ) and pyridine $(5 \mathrm{~mL})$ were dissolved in ethyl alcohol $(50 \mathrm{~mL})$. The mixture was refluxed to complete the reaction while monitoring its course by IR. After cooling to room temperature, the mixture was poured into water. The solid $\mathbf{3}$ thus separated was filtered off, washed with water several times and crystallized from ethanol.

(Z)-(5-Bromo-1-benzofuran-2-yl)(3-methyl-3-phenylcyclobutyl)methanone oxime (3). Yield: $3.57 \mathrm{~g}$ (93\%); m.p.: $193{ }^{\circ} \mathrm{C}$ (from ethanol); IR (KBr): $3201(\mathrm{~N}-\mathrm{OH}), 1602(\mathrm{C}=\mathrm{N}), 1251$ (C-O, on furan ring), 990 (N-O, oxime) [8,9], 544 (C-Br) cm ${ }^{-1} .{ }^{1} \mathrm{H}-\mathrm{NMR}$ (200 MHz; DMSO-d 6 ) $\delta: 1.49$ and 1.54 (two s, 3H, $\mathrm{CH}_{3}$ ), 2.42-2.63 (m, 4H, $\mathrm{CH}_{2}$ ), 3.92 (q, 1H, >CH-), 7.10-7.96 (m, 9H, aromatics), 11.75 and 12.03 (two s, $1 \mathrm{H}, \mathrm{N}-\mathrm{OH})$; ${ }^{13} \mathrm{C}-\mathrm{NMR}(50.34 \mathrm{MHz}$; DMSO-d 6 ) $\delta: 155.17,154.58,153.74,153.23,149.62$, 148.65, 132.08, 131.82, 130.37, 129.94, 127.01, 126.40, 126.24, 126.15, 125.52, 117.27, 117.18, 115.19, 113.70, 106.62, 42.17, 41.60, 40.50, 40.37, 40.29, 40.23, 40.08, 32.10, 31.91. Anal. Calcd. For $\mathrm{C}_{20} \mathrm{H}_{18} \mathrm{BrNO}_{2}$ : C 62.51, H 4.72, N 3.65. Found: C 62.35, H 4.81, N 3.67.

(Z)-(3-Methyl-3-phenylcyclobutyl)(naphtho[2,1-b]furan-2-yl)methanone oxime (4). Yield: $1.81 \mathrm{~g}$ (94\%); m.p.: 205-208 ${ }^{\circ} \mathrm{C}$ (from ethanol); IR (KBr): $1674(\mathrm{C}=\mathrm{O}), 1255$ (C-O, on furan ring) $\mathrm{cm}^{-1},{ }^{1} \mathrm{H}-$

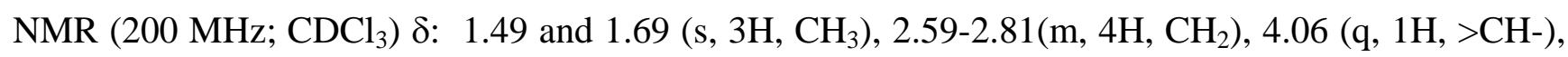
7.14-7.99 (m, 12H, aromatics), 11.64 and 11.88 (two s, $1 \mathrm{H}, \mathrm{N}-\mathrm{OH} ;{ }^{13} \mathrm{C}-\mathrm{NMR}\left(50.34 \mathrm{MHz} ; \mathrm{CDCl}_{3}\right.$ ) $\delta$ : 154.09, 153.42, 152.05, 147.86, 132.44, 130.79, 130.27, 130.18, 129.39, 128.72, 127.29, 126.88, 126.73, 126.62, 125.84, 125.47, 124.87, 115.14, 114.24, 41.22, 40.73, 33.30, 32.23; Anal. Calcd. For $\mathrm{C}_{24} \mathrm{H}_{21} \mathrm{NO}_{2}$ : C 81.10, H 5.96, N 3.94. Found: C 81.00, H 5.96, N 3.77.

General procedure for the synthesis of oxyranyl compounds 5 and $\mathbf{6 .}$

In a two necked $250 \mathrm{~mL}$ reaction flask equipped with a reflux condenser and a dropping funnel, 3 (3.83 g, $10 \mathrm{mmol}$ ) was dissolved in dry acetone $(50 \mathrm{~mL})$. To this solution powdered $\mathrm{KOH}(1.68 \mathrm{~g}, 30$ 
mmol) was added portions over a $1 \mathrm{~h}$ period. Subsequently, epichlorohydrin ( $2 \mathrm{~mL}, 30 \mathrm{mmol}$ ) was added in 15 minutes and the solution was refluxed for $8 \mathrm{~h}$. The solvent was removed under reduced pressure and the residue was treated with diethyl ether, the etheral phase dried over anhydrous $\mathrm{MgSO}_{4}$, filtered and the ether was removed under reduced pressure. Thus obtained solid substance $\mathbf{5}$ was crystallized from ethanol.

(Z)-(5-Bromo-1-benzofuran-2-yl)(3-methyl-3-phenylcyclobutyl)methanone O-(oxiran-2-yl-methyl)oxime (5). Yield: 3.04 g (69\%); m.p.: 139-142 ${ }^{\circ} \mathrm{C}$ (from ethanol); IR (KBr): 1594 (C=N), 1253 (C-O, on furan ring), 1053 and 1031 (C-O, epoxide), 979 (N-O, oxime) [8,9], 541 (C-Br) cm ${ }^{-1} .{ }^{1} \mathrm{H}-\mathrm{NMR}$ (200 $\mathrm{MHz} ; \mathrm{CDCl}_{3}$ ) $\delta: 1.57$ and 1.62 (two s, $3 \mathrm{H}, \mathrm{CH}_{3}$ ), 2.47-2.74 (m, 4H, $\mathrm{CH}_{2}$ ), 2.87 (t, J=6.9 Hz, 2H, $-\mathrm{CH}_{2^{-}}$ O), 3.33 (m, 1H, >CH-O), 3.90 (q, 1H, >CH-), 4.12-4.50 (four d, 2H, N-O-CH $2^{-}$), 7.13-7.77 (m, 9H, aromatics); ${ }^{13} \mathrm{C}-\mathrm{NMR}\left(50.34 \mathrm{MHz} ; \mathrm{CDCl}_{3}\right.$ ) $\delta: 154.21,154.12,151.00,149.54,132.27,130.99,130.16$, 127.28, 126.71, 126.14, 118.15, 114.97, 114.86, 77.73, 51.98, 46.79, 41.14, 40.58, 33.26, 32.33. Anal. Calcd. For $\mathrm{C}_{23} \mathrm{H}_{22} \mathrm{BrNO}_{2}$ : C 65.10, H 5.23, N 3.30. Found: C 65.20, H 4.97, N 3.21.

(Z)-(3-Methyl-3-phenylcyclobutyl)(naphtho[2,1-b]furan-2-yl)methanone O-(oxiran-2-yl-methyl)oxime (6). Yield: 0.28 g (67\%); m.p.: 205-207 ${ }^{\circ} \mathrm{C}$ (from ethanol); IR (KBr): $1674(\mathrm{C}=\mathrm{O}), 1255$ (C-O, on furan ring) $\mathrm{cm}^{-1}$; ${ }^{1} \mathrm{H}-\mathrm{NMR}\left(200 \mathrm{MHz} ; \mathrm{CDCl}_{3}\right) \delta: 1.66\left(\mathrm{~s}, 3 \mathrm{H}, \mathrm{CH}_{3}\right), 2.53-2.75\left(\mathrm{~m}, 4 \mathrm{H}, \mathrm{CH}_{2}\right), 2.86(\mathrm{t}$, $\mathrm{CH}_{2}-\mathrm{O}$ ), 3.28 (m, $1 \mathrm{H},>\mathrm{CH}-\mathrm{O}$ ), 4.00 (q, $1 \mathrm{H},>\mathrm{CH}-$ ), 4.21-4.53 (four d, 2H, N-O-CH- ), 7.17-8.23 (m, $12 \mathrm{H}$, aromatics); ${ }^{13} \mathrm{C}-\mathrm{NMR}\left(50.34 \mathrm{MHz} ; \mathrm{CDCl}_{3}\right) \delta: 154.26,153.41,151.29,148.07,132.43,130.76$, 130.15, 129.33, 128.69, 127.24, 126.85, 126.77, 125.80, 125.53, 114.82, 114.64, 114.21, 77.56, 52.14, 46.92, 41.18, 40.72, 33.34, 32.35.Anal. Calcd. For $\mathrm{C}_{27} \mathrm{H}_{25} \mathrm{NO}_{2}$ : C 82.00 5, H 6.37, N 3.54. Found: C 82.21, H 6.44, N 3.29 .

General procedure for the synthesis of thiosemicarbazones $\mathbf{7}$ and $\mathbf{8}$.

A mixture of 1 (0.369 g, $1.0 \mathrm{mmol})$, thiosemicarbazide $(0.091 \mathrm{~g}, 1.0 \mathrm{mmol})$ and $p$-toluene sulphonic acid $(0.010 \mathrm{~g}$, as catalyst) in absolute ethanol $(50 \mathrm{~mL})$ was refluxed. The course of the reaction was monitored by TLC. After the solvent was removed under reduced pressure, the residue was treated with water and solid product 7 thus obtained was recrystallized from methanol.

(Z)-(5-Bromo-1-benzofuran-2-yl)(3-methyl-3-phenylcyclobutyl)methanone thiosemicarbazone

Yield: 0.42 g (94\%); m.p.: $219{ }^{\circ} \mathrm{C}$ (from ethanol); IR (KBr,): 3432-3155 (four sharp peaks, thiosemicarbazide), $1598(\mathrm{C}=\mathrm{N}), 1244$ (C-O, on furan ring), $1045(\mathrm{C}=\mathrm{S}), 547(\mathrm{C}-\mathrm{Br}) \mathrm{cm}^{-1}$. ${ }^{1} \mathrm{H}-\mathrm{NMR}$ $\left(200 \mathrm{MHz} ; \mathrm{CDCl}_{3}\right) \delta: 1.61$ (s, 3H, $\mathrm{CH}_{3}$ ), 2.47-2.72 (m, 4H, $-\mathrm{CH}_{2}-$ ), 3.70 (q, 1H, >CH-), 6.32 (broad s, $2 \mathrm{H},-\mathrm{NH}_{2}$ ), 7.02-7.80 (m, 9H, aromatics), 10.82 (s, $\left.1 \mathrm{H},-\mathrm{NH}-\right) ;{ }^{13} \mathrm{C}-\mathrm{NMR}\left(50.34 \mathrm{MHz} ; \mathrm{CDCl}_{3}\right) \delta$ : 181.48 (C=S), 155.30, 153.37, 151.87, 141.16, 132.15, 130.39, 130.33, 127.66, 126.71, 126.56, 119.41, 115.52, 111.74, 41.00, 40.82, 34.96, 32.55. Anal. Calcd. For $\mathrm{C}_{21} \mathrm{H}_{20} \mathrm{BrN}_{3} \mathrm{OS}$ : C 57.02, H 4.56, N 9.50, S 7.25. Found: C 57.35, H 4.67, N 9.80, S 7.44.

(Z)-(3-Methyl-3-phenylcyclobutyl)(naphtho[2,1-b]furan-2-yl)methanone thiosemicarbazone (8). Yield: 0.38 g (91\%); m.p.: $217^{\circ} \mathrm{C}$ (from ethanol); IR (KBr): $1674(\mathrm{C}=\mathrm{O}), 1255$ (C-O, on furan ring) $\mathrm{cm}^{-1}$; ${ }^{1} \mathrm{H}-$ NMR (200 MHz; $\mathrm{CDCl}_{3}$ ) $\delta: 1.65$ (s, 3H, $\mathrm{CH}_{3}$ ), 2.53-2.77 (m, 4H, $\mathrm{CH}_{2}$ ), 3.84 (q, 1H, >CH-), 6.31 
(broad s, 2H, - $\mathrm{NH}_{2}$ ), 7.15-8.21 (m, 12H, aromatics), 10.99 (s, 1H, -NH-); ${ }^{13} \mathrm{C}-\mathrm{NMR}$ (50.34 MHz; $\left.\mathrm{CDCl}_{3}\right) \delta$ : $181.38(\mathrm{C}=\mathrm{S}), 154.84,153.52,150.36,141.69,132.71,131.12,130.70,130.39,129.48$, 129.26, 127.62, 126.61, 126.53, 125.33, 124.22, 114.32, 111.67, 41.13, 40.86, 34.98, 32.63. Anal. Calcd. For $\mathrm{C}_{25} \mathrm{H}_{23} \mathrm{~N}_{3} \mathrm{OS}$ : C 72.61, H 5.61, N 10.16, S 7.75. Found: C 72.98, H 5.68, N 10.23, S 7.82.

General procedure for the synthesis of thiazolyl hydrazones $\mathbf{9}$ and $\mathbf{1 0 .}$

A mixture of of $7(0.442,1.0 \mathrm{mmol})$ and dichloroacetone $(0.127 \mathrm{~g}, 1.0 \mathrm{mmol})$ in dry acetone (40 $\mathrm{mL}$ ) was stirred at room temperature. The course of the reaction was monitored by TLC. After completing the reaction, the solution was then made alkaline with an aqueous solution of $\mathrm{NH}_{3}$ (5\%). The precipitate was filtered off, washed with same $\mathrm{NH}_{3}$ solution several times, dried in air and crystallized from EtOH and dried and stored in a desiccator over $\mathrm{CaCl}_{2}$.

(Z)-(5-Bromo-1-benzofuran-2-yl)(3-methyl-3-phenylcyclobutyl)methanone[4-(chloromethyl)-1,3thiazol-2-yl]hydrazone (9). Yield: 0.29 g (57\%); m.p.: $199{ }^{\circ} \mathrm{C}$ (from acetone); IR (KBr): 3351 (-NH-), $1598(\mathrm{C}=\mathrm{N}), 1258$ (C-O, on furan ring), $762(\mathrm{C}-\mathrm{Cl}), 542(\mathrm{C}-\mathrm{Br}) \mathrm{cm}^{-1} ;{ }^{1} \mathrm{H}-\mathrm{NMR}\left(200 \mathrm{MHz} ; \mathrm{CDCl}_{3}\right) \delta$ : 1.63 (s, 3H, $\left.\mathrm{CH}_{3}\right), 2.46-2.79\left(\mathrm{~m}, 4 \mathrm{H}, \mathrm{CH}_{2}\right), 3.68$ (q, 1H, >CH-), 4.54 (s, 2H, $\left.-\mathrm{CH}_{2}-\mathrm{Cl}\right), 6.67(\mathrm{~s}, 1 \mathrm{H}$, aromatic in thiazole), 6.94-7.77 (m, 9H, aromatics), 10.99 (broad s, $1 \mathrm{H},-\mathrm{NH}-)$; ${ }^{13} \mathrm{C}-\mathrm{NMR}(50.34 \mathrm{MHz}$; $\left.\mathrm{CDCl}_{3}\right) \delta:$ 171.66, 153.51, 151.78, 141.26, 132.39, 130.88, 130.64, 130.14, 128.28, 127.12, 126.17, 126.04, 125.90, 124.78, 114.27, 111.75, 43.41, 41.23, 40.49, 34.88, 32.38; Anal. Calcd. For $\mathrm{C}_{24} \mathrm{H}_{21} \mathrm{ClBrN}_{3} \mathrm{OS}$ : C 55.99, H 4.11, N 8.16, S 6.23. Found: C 56.02, H 4.21, N 8.04, S 6.33.

(Z)-(3-Methyl-3-phenylcyclobutyl)(naphtho[2,1-b] furan-2-yl)methanone[4-(chloromethyl)-1,3-thiazol2-yl]hydrazone (10). Yield: 0.30 g (61\%); m.p.: $207^{\circ} \mathrm{C}$ (from acetone); IR (KBr): 1674 (C=O), 1255 (C-O, on furan ring) $\mathrm{cm}^{-1}$; ${ }^{1} \mathrm{H}-\mathrm{NMR}\left(200 \mathrm{MHz} ; \mathrm{CDCl}_{3}\right) \delta$ : $1.68\left(\mathrm{~s}, 3 \mathrm{H}, \mathrm{CH}_{3}\right), 2.52-2.87\left(\mathrm{~m}, 4 \mathrm{H},-\mathrm{CH}_{2}-\right.$ ), 3.84 (s, $1 \mathrm{H},>\mathrm{CH}-), 4.56$ (s, $\left.2 \mathrm{H},-\mathrm{CH}_{2}-\mathrm{Cl}\right), 6.67$ (s, $1 \mathrm{H}$, aromatic in thiazole), 7.14-8.21 (m, 12H, aromatics), 10.85 (broad s, -NH-). ${ }^{13} \mathrm{C}-\mathrm{NMR}\left(50.34 \mathrm{MHz} ; \mathrm{CDCl}_{3}\right.$ ) $\delta: 172.24,153.72,151.09,140.26$, 132.66, 131.03, 130.63, 130.26, 129.93, 129.53, 129.05, 127.42, 127.33, 126.80, 126.41, 125.37, 124.51, 114.27, 110.30, 109.90, 43.61, 41.10, 40.59, 34.91, 32.34. Anal. Calcd. For $\mathrm{C}_{28} \mathrm{H}_{24} \mathrm{ClN}_{3} \mathrm{OS}$ : C 69.19, H 4.98, N 8.65, S 6.60. Found: C 69.09, H 4.98, N 8.82, S 6.63.

\section{Preparation of microbial cultures}

Microorganisms were provided from the culture collection of the Microbiology Laboratory of the Biological Sciences of Faculty of Science and Arts, Firat University, Turkey. In this work, Bacillus subtilis LM622 (B.s.), Enterobacter aeruginosa CCM 2531 (E.a.), Eschericia coli ATCC 25922 (E.c.), Listeria monocytogenes SCOTTA (L.m.), Pseudomonas aeruginosa DSM 50071 (P.a.), Staphilococcus aureus COWAN I (S.a.) Candida albicans FMC 17 (C.a.), and Saccharomyces cerevisiae FMC 16 (S.c.) were used to investigate the bacteriological and antifungal activities of selected substances. The bacteria and yeast strains were nourished in nutrient broth (Difco) and in malt extract broth (Difco), and incubated for 24 and 48 h, respectively. In the Disc Diffusion method, sterile Mueller Hinton Agar (Oxoid) for bacteria and Saburoud Dextrose Agar for yeast were separately inoculated with the test microorganisms. The compounds, dissolved in DMSO as 500 
$\mu \mathrm{g} / \mathrm{disc}$ solutions, were placed in wells (6 $\mathrm{mm}$ diameter) in the agar media and the plates were incubated at $32{ }^{\circ} \mathrm{C}$ for bacteria (18-24 h) and at $25^{\circ} \mathrm{C}$ for yeast (72 h) [12]. The resulting inhibition zones on the plates were measured in mm after $48 \mathrm{~h}$ (Table 1). The control samples only contained DMSO. The data reported in Table 1 represent the average of three experiments.

\section{References}

1. Masubuchi, M.; Kawasaki, K.; Ebiike, H.; Ikeda, Y.; Tsujii, S.; Sogabe, S.; Fujii, T.; Sakata, K.; Shiratori, Y.; Aoki, Y.; Ohtsuka, T.; Shimma, N. Design and Synthesis of Novel Benzofurans as a New Class of Antifungal Agents Targeting Fungal N-Myristoyltransferase, Part 1. Bioorg. Med. Chem. Lett. 2001, 11, 1833-1837.

2. Whomsley, R.; Fernandez, E.; Nicholls, P.J.; Smith, H.J.; Lombardi, P.; Pestellini, V. Substituted 1-[(Benzofuran-2-yl)-Phenylmethyl]-Imidazoles as Potent Inhibitors of Aromatase In vitro and in Female Rats In vivo. J. Steroid Biochem. 1993, 44, 675-676.

3. Sancar, A. Structure and Function of DNA Photolyase. Biochemistry, 1994, 33, 2-9.

4. Helis, P.F.; Hartman, R.F.; Rose, S.D. Photoenzymic Repair of UV-Damaged DNA - A Chemists Perspective. Chem. Soc. Rev. 1995, 24, 289-\&.

5. Bren, V.A.; Dubonosov, A.D.; Minkiin, V.I.; Chernoivanov, V.A. Norbornadene-Quadricyclane as Efficient Molecular-System of Accumulation of Solar-Energy. Usp. Khim. 1991, 60, 913-948.

6. Yoo, S.E.; Lee, S.H.; Kim, S.K.; Lee, S.H. The Conformation and Activity Relationship of Benzofuran Derivatives as Angiotensin II Receptor Antagonists. Bioorgan. \& Med. Chem. 1997, 5, 445-459

7. Ward, R.S. Lignans, Neolignans and Related Compounds. Nat. Prod. Rep. 1999, 16, 75-96

8. Akhmedov, M.A.; Sardarov, I.K.; Akhmedov, I.M.; Kostikov, R.R.; Kisin, A.V.; Babaev, N.M. Formation of Substituted-Cyclobutanes In the Reaction of 2-(2-Methyl-2-propenyl)-3Chloromethyloxirane with Aromatic-Hydrocarbons. Zh. Org. Khim. 1991, 27, 1434-1440.

9. Abele, E.; Popelis, Y.; Gavars, M.; Gaukman, A.; Shimanska, M.; Lukevich, E. O-Acylation of Furan and Thiophene Ketoximes Under Liquid-Solid Phase-Transfer Catalysis Conditions. Khim. Geterotsikl. 1994, 7, 886-890.

10. Shridhar, D.R.; Sastry, C.V. R.; Chaturvedy, S.C.; Grumurthy, R.; Sing, P.P.; Rao, C.S.; Junnarkar, A.Y. Synthesis and Pharmacology of Some New Oxime Ethers Derived From 2Acetyl-5-Arylthiophenes. Indian J. Chem. 1984, 23, 692-694.

11. Sinha, A.K.; Rastogi, S.N.; Patnaik, G.K.; Srimal, R.C. Synthesis of Oxime Ether Derivatives of Beta-Arylpropiophenones and 2-p-Methoxybenzylindan-1-one as Potential Antiinflammatory and Antiulcer Agents. Indian J. Chem. 1993, 32, 738-745.

12. Collins, C.H.; Lyne, P.M.; Granga, J.M. Microbiological Methods, $6^{\text {th }}$ Ed.; Butterworths Co. Ltd.: London, 1989; p. 410

Sample Availability: Available from the authors.

(C) 2005 MDPI (http://www.mdpi.com). Reproduction is permitted for noncommercial purposes 